\title{
Coping with a Closed and Politicized System: The Advisory Roles of Political Scientists in Hungary
}

\author{
Gábor Tamás Molnár
}

\subsection{Introduction: An Emerging Discipline in a Democratic System Under Pressure}

Studying the policy advisory roles of Hungarian political science helps bridge two significant gaps in our knowledge. Hungary can be described as an exemplary case of an illiberal democracy (Hajnal \& Rosta, 2019; Korkut, 2012) and also of populist policymaking (Bartha et al., 2020). However, there is almost no systematic knowledge of policy advice in Hungary (Hajnal et al., 2018b: 451), and understanding how a specific professional community engages in it can contribute to understanding how recent developments structure it as a whole. Can we find elements of an emerging populist policy advisory system? The second puzzle concerns the study of academic professional communities: how do they fit into such

\footnotetext{
G. T. Molnár (四)

Department of Public Policy and Management, Corvinus University of Budapest, Budapest, Hungary

e-mail: gabortamas.molnar@uni-corvinus.hu

(C) The Author(s) 2022

181

M. Brans, A. Timmermans (eds.), The Advisory Roles of Political

Scientists in Europe, https://doi.org/10.1007/978-3-030-86005-9_9
} 
a policy advisory system? This chapter aims to be a stepping stone in our understanding of activities of political science scholars and their position in the Hungarian policy advisory system.

The study's first goal is to consider the applicability of the theoretical framework used in this book to the Hungarian case. We can utilize the specifics of the Hungarian case to formulate expectations on the policy advisory role of political scientists in that country. Our first research question is how can we use our theoretical framework to describe the patterns of policy advisory activities of political scientists in Hungary? The survey enables us to examine the involvement of political scientists in policy advising, with a specific focus on the kind of advisory strategies enabling them to enter the advisory system and the relationship between the strategies adopted and our ideal types of advisory role. In the Hungarian case we can use findings regarding the activities and views of political scientists in order to draw a picture of what is a relatively unknown national policy advisory system. Although political science is a comparatively new discipline in Hungary, it is not any less important than elsewhere (Ilonszki \& Roux, 2019 ) but, on the contrary, represents an important segment of potential academic policy advice, especially if we consider the relevance of political science and public policy knowledge to a nation's policymakers.

This chapter will then go on to explain the level of engagement of political scientists and to look at the supply (push) and demand (pull) factors at play. The survey used in this chapter offers us an idea of the features of Hungarian political science and of the determinants of the supply of advice by political scientists, as well as of the way in which the policy advisory system in Hungary provides opportunities for, or limits, the demand for such advice.

In order to provide some answers to such questions, Sect. 9.2 offers an overview of the known features of Hungarian policymaking and Hungarian political science. We have a handful of existing findings on specific aspects of the policy advisory system, such as think tanks (Bíró-Nagy, 2019) and the internal advisory capacities of the government (Hajnal et al., 2018a). The chapter thus begins by connecting these fragments with known features of the populist policy process (Bartha et al., 2020) to formulate expectations regarding those factors affecting demand for policy advice. It then turns to the supply factors by formulating expectations about the advisory activities of political scientists. Section 9.3 discusses the results of our survey in relation to these expectations. Section 9.4 then concludes the chapter with a discussion of the results, highlighting themes of interest for policy advice scholarship. 


\subsection{The Policy Advisory System and Political SCIENTISTS In Hungary}

This overview of Hungarian policy advice in the policy process is structured along the locational model presented in Chap. 2. First, features of the government system and its environment are presented. Then certain important characteristics of the political science community are illustrated, followed by expectations regarding political scientists' role in the policy advisory system of the country.

\subsubsection{Political and Public Arenas}

Hungarian democracy emerged as a mix of consensus and majoritarian democracy with both neo-corporatist and pluralist elements after the regime change in 1989. Its neo-corporatist elements waned in favour of majoritarianism (Körösényi et al., 2009). The two main trends in Hungarian politics were an increasingly adversarial dynamic of intense partisan competition between emerging ideological blocs and the centralization of political power leading away from a chancellor-parliamentary system towards a quasi-presidential one (Körösényi, 2003). This coincided with the centralization of policymaking and advisory capacities within government. This centralization also manifested itself between levels of government, with a system of fragmented, weak local governments and even weaker regional governments (Hajnal \& Rosta, 2019).

In line with the increasing partisan polarization, politicization has become a major feature of Hungarian public administration (MeyerSahling, 2006), with recent studies pointing to medium to high levels of it (Meyer-Sahling \& Veen, 2012; Staroňová \& Gajduschek, 2013; Ványi, 2018). Political logic pervades even the lower levels of bureaucracy, which suggests the politicization of most recipients of policy advice as well. Even without taking account of political considerations, public administration in Hungary is inherently unreceptive to political science expertise, with its highly legalist Rechtstaat tradition and the continued dominance of lawyers in bureaucracy (Gajduschek, 2012; Hajnal \& Ványolós, 2013). This continuing legalist administrative approach is thus expected not to be open to political science and public policy-based approaches to policymaking, when compared to input from the fields of economics and sociology even. 
In seeking to understand the logic of Hungarian policymaking over the last decade, we can draw on three systematic scientific attempts to label the country's political evolution. Hungary has been defined as an illiberal democracy (Korkut, 2012; Mudde \& Jenne, 2012; Szelényi \& Csillag, 2015), a populist democracy (Bartha et al., 2020; Pappas, 2014), and a plebiscitary leader democracy (Körösényi et al., 2020).

Centralization has continued within central government: the prime minister's office occupies the central position, while there has been a reduction in the autonomy afforded to the various ministries (Körösényi et al., 2020). The underlying logic of the system is that of political governance, as characterized by centralization and strong political control over the whole government (Hajnal et al., 2018a). This has led to substantive policy expertise playing a very marginal role, subordinated as it is to political considerations. Outside of central government, the country's already weak local governments have seen their powers weakened even further in the existing illiberal era (Hajnal et al., 2018b; Hajnal \& Rosta, 2019).

Political governance also implies a 'radically accelerated, top-down, unilateralist style of policy making' along with the 'lack of evidence-based policy making practices' (Hajnal et al., 2018a: 32-33). The ideological character of illiberal-populist governance is anti-elitist and often antiintellectual, considering political will superior to scientific expertise with regard to policy questions. Populist governments do rely on expert political advice, but they do so under their own terms, framed by the political logic of the regime.

This anti-pluralist governance logic implies the further politicization of previously partially autonomous spheres such as the media, the economy, and public administration. Potential sources of policy advice are included or excluded, based on their personal and political connections. While this dynamic may not apply to occasional contributors, the choice is often between co-optation and exclusion for those regularly involved in policy matters.

While the populist logic may run counter to the idea of autonomous spheres of expertise, its dependence on maintaining popular support calls for the participation of scientific advisors in two ways: in political polling and consulting as experts, on the one hand, and in political windowdressing or public legitimation activities as opinionating scholars, on the other. Normative advice can be expected, because while populist governance is ideologically very flexible, it still requires normative justification for legitimacy purposes. In the Hungarian case, this ideological basis of 
governance in the 2010s, called ethno-nationalism (Bozóki \& Hegedüs, 2018) or post-communist neo-conservatism (Szelényi \& Csillag, 2015), was cultivated on a strong philosophical and normative social scientific basis. This need generated a diverse group of political consultants (ranging from theorists to experts in political practice) tied to the centre of power, providing policy ideas and tracking what is salient or politically feasible.

A growing outsourcing of advice has led to a diminishing of the internal advisory capacity and role of cabinets and mandarins (Hajnal et al., 2018b). A growing sector populated by various applied research institutes and think tanks has taken their place in the policymaking sphere.

Hungarian think tanks fall into two categories: government-linked think tanks (and applied research institutes) and opposition-oriented think tanks (Bíró-Nagy, 2019). Those in the first category are characterized by their strong political ties to the government, and while they fulfil think tank functions publically, their main functions locate them within the internal government arena. Think tanks sponsored by the government work in an almost identical way to applied research institutes: both deliver knowledge to government and party politicians, while at the same time engaging in public debate to legitimize governmental policies and narratives. There is no clear dividing line between applied research institutes and think tanks on the government's side, as some organizations fulfil both roles and party and government operations largely merge. While a couple of think tanks have enjoyed stable central contracts (Bíró-Nagy, 2019), the sphere of applied policy research institutes is characterized by higher institutional volatility. Both kinds of organization are generally awarded steady, substantial government contracts, with the corresponding portfolios ranging from policy-oriented studies to political communication.

The societal arena of the Hungarian policy advisory system consists of non-governmental think tanks and political consultancy firms, civil society, and economic actors involved in the policy process. The most important group of non-government-linked political advisors are those working for think tanks and political consulting firms. Opposition think tanks often rely on marketized advice and foreign funding to survive (Bíró-Nagy, 2019). Most think tanks also offer political consulting services, whereas a couple lack the ideological profile generally associated with think tanks.

Since in an illiberal system, the centre of power does not tolerate institutionalized checks and balances, civil society is weak and often dependent 
on party politics and the government. Non-governmental policy actors have little influence on the policymaking process, which is dominated by the central executive (Boda \& Patkós, 2018; Hajnal et al., 2018b). Since civil society cannot influence domestic policymaking directly (Bartha et al., 2020), the effect of such actors is conveyed through the media or through international organizations. The final important group in the external arena consists of international organizations, and in particular the European Union (EU): these have important roles in many policy areas due to their position as the final hard constraint on the government's room for manoeuvre (Bozóki \& Hegedűs, 2018).

\subsubsection{Expectations on Advising Activities}

This section examines the supply factors underlying advice provision by the political science community and the extent to which this community produces and divulges knowledge of relevance to policy. Hajnal et al. (2018a, 2018b) note that the lack of evidence-based policymaking in Hungary is due not just to demand factors but also to academia's lack of capacity. Although this is a circular problem, we can argue that it partially stems from the structure of the Hungarian political science community. In line with the legalistic traditions of the country, state sciences (Staatswissenschaft) have developed as, and remained, a separate discipline from political sciences, thus maintaining a tradition that prioritizes legal procedure over policy considerations (Gajduschek, 2012). This was a major obstacle for the institutionalization of policy studies. While public policy and public administration developed as semi-autonomous disciplines, distinct from the rest of political sciences, their institutional positions remain rather weak (Hajnal, 2020). Furthermore, the study of international relations developed separately from the rest of political science and is mostly detached from the population of scholars studied in the country chapters in this book.

The political science community has become increasingly internationalized, conforming to European academic standards and research directions, albeit only for a core group of academics (Molnár \& Ilonszki, 2021). One expectation is that the international or supranational level of advisory activities will only be significant for a select group of internationalized academics. They are likely to be found in the very best research institutes and universities, as well as in those think tanks and NGOs which are not 
funded by government and therefore have to rely on foreign donors and partners to an increasing degree as part of their diversification strategy.

The second question concerning supply-side factors is the willingness of political scientists in Hungary to act as advisors. This will depend on their intrinsic motivation to do so, or their reservations about advisory activity, and also on the external incentives provided by the institutional context. Depending on the prevailing professional norms and on their own personal convictions, academics may have reservations about engaging with their subject matter in an advisory capacity, or they may consider advisory engagement to be one of their professional obligations. The external incentives defined by academic and applied scientific institutions can reinforce either of these considerations by rewarding or disregarding advisory impact.

During the democratic transition and the formative years of Hungarian political science, a strong tradition of public intellectuals prevailed, where public and political engagement was the norm among academics (Szabó, 2010). During the professionalization of the discipline in the 2000s, increasing emphasis was placed on value-neutral, internationally relevant scientific work. This meant the introduction of incentive systems (mostly publication criteria) which made it very difficult for upcoming scholars to focus on advisory careers while advancing in academia. As Hungarian political science is a young discipline, and is thus mainly concerned with its professionalization and academic institutionalization, one may expect to find a low sense of professional obligation to engage in policy advice among its members.

By the time of this survey, the 'impact agenda' had not reached Hungary yet, with practically no impact incentives included in performance evaluation or promotion criteria, and only social relevance included as a secondary consideration for research funding (Bandola-Gill et al., 2018). This basically means that the way is open for academics to engage in advisory activities based on their personal values but is not incentivized in any way. This, combined with the considerable publication and teaching requirements at most universities, means that we can expect advisory activities to happen mainly as a result of economic considerations. The key monetary incentive is expected to come in the form of the extra income provided by the advisory activity itself, as government or private consulting contracts can provide much higher income than academic work can. Services are provided through external institutions and are not linked to academic positions. Therefore, academics working outside of academia (for think 
tanks, applied scientific institutes, or political consultancy firms) can be expected to be much more active as policy advisors. Furthermore, there may be a sharp division between the pure academics with substantial professional reservations about advisory engagement, and their more engaged colleagues who are likely to feel an obligation to provide advice, or at least fewer reservations about doing so, since the institutional landscape alone will not be enough to encourage their involvement.

The country's political and governmental arrangements would suggest that most of the demand for policy advice arises at national government level, where it is concentrated around the centre of executive power. Opposition parties and international organizations should represent two further important recipients of advice, while others will only have marginal roles. Along with the major influence of government over much of the media, this means that experts who do not have access to government insiders are going to have very few channels available to them by which to influence policies; these channels will mainly consist of opposition parties and their corresponding think tanks. Unfavourable traditions, together with recent developments in policymaking, suggest that the overall level of demand for most sub-disciplines of political science will be low.

Based on policy process characteristics, our expectations are in keeping with Hajnal et al.'s recent expert assessment that at the national policymaking level, 'external expertise is dominant; as far as it can be judged a very narrow circle of (mostly) informal sources of policy advice dominates the fields' (Hajnal et al., 2018b: 451). There are three key expectations here: the main channels of advice are likely to involve externalization with (quasi-)marketization instead of internal positions; the dominance of central government's political will and the closed nature of the policy process would seem to suggest selective advisory access to the politicized arenas; and the key importance of personal, informal connections to gaining that access.

Regarding the content of advice, the logic of populist political governance leads us to expect the diminished role of substantive public policy and public administration considerations, while political consulting and opinion polling are expected to be central. The politicized nature of the policy advisory system also means that those involved are likely to provide normative considerations relatively more often (than the European average).

With regard to the four main ideal types, the majority of Hungarian political scientists can be expected to fall into the 'pure academic' 
category, with a minority of them supplying all observable advice. Among those who engage in advisory activities, experts and opinionating scholars are expected to be the main types, more than public intellectuals. Professional reservations against political engagement lead us to expect experts to outnumber opinionating scholars, who may be a smaller active minority. Those academics who have links to the government or to an opposition organization are likely to engage in widespread, informal advisory activities. Those who have no direct access to policymaking are expected to remain pure academics or to utilize alternative pathways in order to have an advisory impact.

\subsection{Empirical Patterns of Advising}

The analysis is based on the results of the survey conducted for this book project. The survey had a 29.3\% response rate in Hungary, with 66 members of the profession answering the questionnaire. The sample slightly over-represents female and younger colleagues, as well as those employed on temporary contracts. The fact that these groups may be less involved in advisory activities could lead to a slight underestimation of the level of engagement in our findings.

\subsubsection{Frequency and Content of Advice}

How active are Hungarian political scientists in policy advisory activities? Table 9.1 shows the frequency of the different forms of advice they provide. Hungarian political scientists are not very active when compared to the European average, as about half of them say they never engage in any of the listed advisory activities. This difference is most striking in relation to the more relevant advisory activities, where only $25 \%$ to $30 \%$ of European respondents never engage in providing data and facts, analysing and explaining causes and consequences or evaluating solutions. Conversely, the figures closest to the European average are observed with regard to the least commonly engaged in advisory activities, such as consultancy and policy recommendations, forecasting, and polling.

Against the backdrop of this generally limited engagement with advising, the most frequent activities are the provision of data and facts and the analysis and explanation of causes and consequences. These are followed by evaluation and consultancy. The activities least frequently engaged in are making value judgments and providing normative arguments. These 


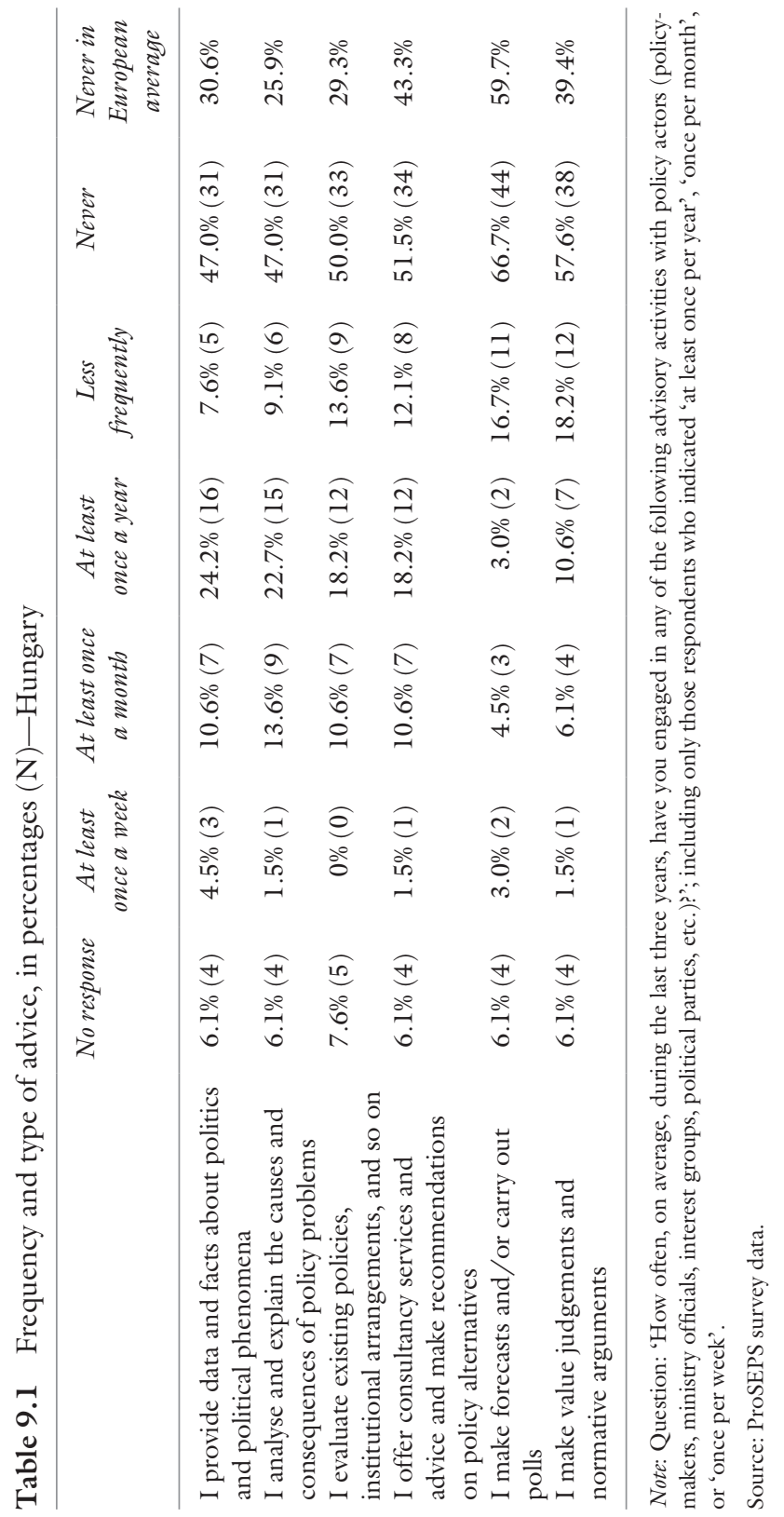


findings contrast with the expectations based on the logic of Hungarian policymaking regarding the importance of normative content. They also indicate that political science in Hungary is either not connected to, or not well-suited for, the kind of advice required by policymakers. This interpretation is supported further by the survey's findings on the substantive topics of advice, where except for a few popular areas such as social welfare and economic policy, advice by Hungarian political scientists is much less likely to have a substantive policy focus than the European average. The most striking difference is the lack of scientific advice on 'government and public administration organization, and electoral reforms', with only $14.3 \%$ of respondents engaged in policy advice indicating this activity, against a European average of $40.8 \%$, and on 'International affairs, development aid, EU' with $17.1 \%$ (compared to $33.8 \%$ in the overall sample). Also the provision of advice on 'civil rights, political rights, and gender issues' is well below average, at just $8.6 \%$ compared to $21.6 \%$ of the total sample in the survey.

The perceptions of political scientists in Hungary on their public visibility are much closer to the average for all countries (54.6\% in Hungary and $55 \%$ on average in Europe). This represents a remarkable discrepancy with the actual activities performed. This may mean that political scientists in Hungary have alternative ways of influencing public debate or that the small group of active scholars establishes the reputation of the category of political scientists as a whole.

\subsubsection{The Supply Aspects of Advice}

To what degree are political scientists in Hungary encouraged to engage in policy advising? The expectation was that the professional-institutional context itself does not provide any really strong incentives to scholars to engage in policy advising. This does not appear true however. Some $40 \%$ of the respondents claim career considerations as part of their advisory motivation, which is higher than the figure of $32.9 \%$ for the overall sample. Incentives from outside the academic sphere seem even more important, as $54.3 \%$ of respondents indicate that alternative sources of income and career options are part of their motivation, which is once again higher than the European average of $42.9 \%$. Low engagement is therefore difficult to account for in terms of perceived external incentives.

The next question to consider is the intrinsic motivation of political scientists to engage in advisory activities. Scholars may have a sense of 
Table 9.2 Normative views on policy advice, in percentages (percentages in overall sample)—Hungary

\begin{tabular}{|c|c|c|c|c|}
\hline $\begin{array}{l}n=63(n=2354 \\
\text { in overall sample })\end{array}$ & Fully agree & $\begin{array}{l}\text { Somewhat } \\
\text { agree }\end{array}$ & $\begin{array}{l}\text { Somewhat } \\
\text { disagree }\end{array}$ & Fully disagree \\
\hline $\begin{array}{l}\text {...should become } \\
\text { involved in } \\
\text { policymaking }\end{array}$ & $16.7 \%(23.4 \%)$ & $51.5 \%(45.5 \%)$ & $28.8 \%(21.4 \%)$ & $3 \%(5.6 \%)$ \\
\hline $\begin{array}{l}\text {...have a professional } \\
\text { obligation to engage in } \\
\text { public debate }\end{array}$ & $16.7 \%(29.3 \%)$ & $40.9 \%(43.3 \%)$ & $28.8 \%(16.9 \%)$ & $13.6 \%(8.2 \%)$ \\
\hline $\begin{array}{l}\text {...should provide } \\
\text { evidence-based } \\
\text { knowledge and } \\
\text { expertise outside } \\
\text { academia, but not be } \\
\text { directly involved in } \\
\text { policymaking }\end{array}$ & $28.8 \%(24.2 \%)$ & $40.9 \%(36.8 \%)$ & $24.2 \%(25.6 \%)$ & $6.1 \%(9.4 \%)$ \\
\hline $\begin{array}{l}\text {...should refrain from } \\
\text { direct engagement with } \\
\text { policy actors }\end{array}$ & $9.1 \%(5.4 \%)$ & $15.2 \%(14.8 \%)$ & $31.8 \%(33.9 \%)$ & $42.4 \%(41.8 \%)$ \\
\hline $\begin{array}{l}\text {...should engage in } \\
\text { media or political } \\
\text { advisory activities only } \\
\text { after testing their ideas } \\
\text { in academic outlets }\end{array}$ & $21.2 \%(21.6 \%)$ & $42.4 \%(36.2 \%)$ & $27.3 \%(25.0 \%)$ & $6.1 \%(12.1 \%)$ \\
\hline
\end{tabular}

Note: Question: 'To what extent do you agree with the following statements?'; including only those respondents who indicated 'fully agree' or 'somewhat agree'.

Source: ProSEPS survey data.

professional duty or may seek solutions for practice or may have personal motives. Table 9.2 gives the relative weight of different normative views behind the advisory activities of political scientists in Hungary.

The level of agreement with normative views of the profession reinforces the relevance of incentives for advising, since $68.2 \%$ of Hungarian respondents agree to some extent that academics should be involved in policymaking. A professional obligation to engage in public debate is recognized by $57.6 \%$ (16.7\% fully agree, $40.9 \%$ somewhat agree). Professional reservations do not differ significantly from the European average, where cautious engagement is the norm. Only $24.3 \%$ of respondents in Hungary agree that political scientists should refrain from direct engagement with policy actors. This suggests that supply factors alone cannot explain the 
Table 9.3 Proportion of advisory roles by subfields—Hungary

\begin{tabular}{lcccc}
\hline Subfield & $\begin{array}{c}\text { Pure } \\
\text { academic }\end{array}$ & Expert & $\begin{array}{c}\text { Opinionating } \\
\text { scholar }\end{array}$ & $\begin{array}{c}\text { Public } \\
\text { intellectual }\end{array}$ \\
\hline Social science methods & $57.1 \%$ & $9.5 \%$ & $28.6 \%$ & $4.8 \%$ \\
Comparative politics & $47.4 \%$ & $5.3 \%$ & $42.1 \%$ & $5.3 \%$ \\
Public policy & $27.8 \%$ & $11.1 \%$ & $50.0 \%$ & $11.1 \%$ \\
International relations & $29.4 \%$ & $11.8 \%$ & $47.1 \%$ & $11.8 \%$ \\
Political theory & $53.8 \%$ & $7.7 \%$ & $30.8 \%$ & $7.7 \%$ \\
EU studies & $41.7 \%$ & $16.7 \%$ & $41.7 \%$ & $0.0 \%$ \\
Political institutions & $55.6 \%$ & $33.3 \%$ & $11.1 \%$ & $0.0 \%$ \\
Public administration & $62.5 \%$ & $12.5 \%$ & $25.0 \%$ & $0.0 \%$ \\
Political economy & $33.3 \%$ & $0.0 \%$ & $66.7 \%$ & $0.0 \%$ \\
Electoral behaviour & $33.3 \%$ & $16.7 \%$ & $50.0 \%$ & $0.0 \%$ \\
Security studies & $16.7 \%$ & $50.0 \%$ & $33.3 \%$ & $0.0 \%$ \\
Social movements & $50.0 \%$ & $16.7 \%$ & $33.3 \%$ & $0.0 \%$ \\
Other & $60.0 \%$ & $26.7 \%$ & $13.3 \%$ & $0.0 \%$ \\
Total in Hungary & $47.0 \%$ & $16.7 \%$ & $31.8 \%$ & $4.5 \%$ \\
In overall sample & $20.3 \%$ & $26.6 \%$ & $48.7 \%$ & $4.4 \%$ \\
\hline
\end{tabular}

Note: Question: 'Which categories best describe your area of expertise? Please select the three main categories'.

Source: ProSEPS survey data.

low level of advisory engagement. Yet, given the politicized nature of the policy advisory system, they may contribute to it, as more than two-thirds $(69.7 \%)$ of respondents say they should not be directly involved in policymaking, and $63.6 \%$ believe that they should test ideas in academic outlets before any engagement in policy advising.

What impact does the academic background of respondents have? Table 9.3 shows the distribution of the four ideal types and the subfields of the discipline in which the respondents work. In line with the observation that almost half of Hungarian political scientists never do any advising, $47 \%$ can be qualified as pure academics. This proportion is twice that of the European average. At the other end of the scale we find that, as in all countries, public intellectuals in Hungary are a rare species. The two in-between roles are less prominent due to the prevalence of the pure academic. Experts (16.7\%) are political scientists who generally refrain from offering any explicit normative forms of advice, whilst focusing more on factual knowledge; however, opinionating scholars are considerably more common (31.8\%); these are political scientists who utilize both factual and normative analyses when providing advice. The proportions of experts and 
opinionating scholars in Hungary are well below the European average for the respective categories.

Scholars in the subfields of security studies, public policy, and international relations are most likely to engage in advisory activities, followed by political economists and electoral behaviour specialists. From among the most populous sub-disciplines in our sample, scholars in social science methods, comparative politics, political theory, political institutions, and, in particular, public administration are less likely to engage in advisory activities. This suggests that the unique disciplinary structure of Hungarian political science, with the weak position of public policy and the separation of international and security studies, contributes to the low level of engagement in our sample.

The reservations and obligations regarding advisory engagement show very similar distributions among the four advisory roles. One expected and observable difference is that opinionating scholars and public intellectuals are more likely to see engagement in public debate as a professional obligation (64\% and $100 \%$ agree, respectively, compared to $55 \%$ and $42.9 \%$ of pure academics and experts), since engaging in this type of advisory activity is not linked to strong external incentives.

\subsubsection{Advisory Demand and Features of Advice}

In order to understand the factors behind advisory engagement, we need to return to the demand side. Whom do political scientists advise and how? The data on the recipients of advice are in line with our expectation that the national level of governance prevails, as $68.6 \%$ of those engaged in advice indicated this. The international (25.7\%), European $(20 \%)$, and subnational $(11.4 \%)$ levels of governance remain way below the national level as recipients of advice. Yet, compared to most other countries, Hungary's national and the subnational governance levels feature much less within the advisory scope of the country's political scientists. There are no significant differences in orientation, in terms of the level of governance, among the advisory ideal types.

The most important recipients of advice in Hungary are think tanks $(30.3 \%)$, international organizations (above the European average), and civil society organizations (well below the European average). The relevance of international organizations is somewhat surprising, as Hungarian political science is internationalized to a certain degree only. A mere $19.7 \%$ of respondents have ever held academic positions outside of Hungary, 
which is much lower than the average of $36.8 \%$ in the overall sample. This is reinforced further by our data on the internationalization of research activities. Hungarian political scientists lag behind their colleagues in other European countries when it comes to publishing with international coauthors and in peer-reviewed international journals. It seems that for an internationalized core group of academics, cultivating relations with international organizations is a successful way of achieving an impact in the selective, closed advisory system.

The apparently strong role of think tanks was to be expected, given the strong externalization trends in government. This is reinforced by the below-average share of civil servants $(24.2 \%)$, political parties $(21.2 \%)$, executive politicians (19.3\%), and legislative politicians (18.3\%) among the recipients of advice. For all of them, Hungary scores below the European average. The two least likely recipients highlight the dismantling of neo-corporatist and consultative institutions, as advisory bodies $(10.6 \%)$ and private interest groups $(9.1 \%)$ appear less than half as frequently as in the European sample as a whole.

Our data on the positions of political scientists point towards weak institutional links between academia and policymaking. Of all those with a position outside academia, 32\% of academics never give policy advice, while $66.7 \%$ of the political scientists without such a position stay away from advisory engagements. Likewise, having no experience with a position outside of academia correlates with a much lower likelihood of being an expert or opinionating scholar (11.1\% against $20 \%$ and $16.7 \%$ against $44 \%)$. Hungarian political scientists adapt to institutional incentives by taking up positions in firms much more than the European average (33.3\% compared to $14.7 \%$ ). Some kind of affiliation to a firm also gives a political scientist in Hungary above average leverage as an opinionating scholar. Though their numbers are very limited, the role of public intellectual in Hungary goes with political office more often than indicated for Europe as a whole. This shows the weakness of civil society and that neo-corporatist structures such as interest groups and advocacy organizations are less likely to be the recipients of advice of political scientists. Table 9.4 also shows that while in the overall sample academics holding positions in NGOs engage in policy advising more often than those who are not involved in such organizations, the opposite is true in the Hungarian case.

To get a better understanding of the existing advisory relationships, Table 9.5 shows expectations regarding the formality/informality of advice. 
Table 9.4 Advisory roles by positions outside academia, in percentages (percentages in overall sample)-Hungary

\begin{tabular}{lcccc}
\hline Position in & $\begin{array}{c}\text { Pure } \\
\text { academic }\end{array}$ & Expert & $\begin{array}{c}\text { Opinionating } \\
\text { scholar }\end{array}$ & $\begin{array}{c}\text { Public } \\
\text { intellectual }\end{array}$ \\
\hline ..political office & $35.3 \%(12.7 \%)$ & $17.6 \%(25.0 \%)$ & $35.3 \%(53.8 \%)$ & $11.8 \%(8.5 \%)$ \\
Not selected & $51.0 \%(23.0 \%)$ & $16.3 \%(27.2 \%)$ & $30.6 \%(46.8 \%)$ & $2.0 \%(3.0 \%)$ \\
$\ldots$. interest group & $57.1 \%(8.0 \%)$ & $14.3 \%(24.7 \%)$ & $28.6 \%(58.2 \%)$ & $0.0 \%(9.1 \%)$ \\
or advocacy & & & & \\
Not selected & $45.8 \%(22.0 \%)$ & $16.9 \%(26.8 \%)$ & $32.2 \%(47.4 \%)$ & $5.1 \%(3.8 \%)$ \\
$\ldots$ firm & $18.2 \%(13.6 \%)$ & $22.7 \%(24.9 \%)$ & $54.5 \%(53.9 \%)$ & $4.5 \%(7.5 \%)$ \\
Not selected & $61.4 \%(21.5 \%)$ & $13.6 \%(26.8 \%)$ & $20.5 \%(47.8 \%)$ & $4.5 \%(3.9 \%)$ \\
\hline
\end{tabular}

Source: ProSEPS survey data.

Table 9.5 Formality/informality of advice by recipients, in percentages (percentages in overall sample)-Hungary

\begin{tabular}{lccc}
\hline $\begin{array}{l}\text { Recipient groups ( } n \text { of cases where } \\
\text { recipient is selected) }\end{array}$ & $\begin{array}{c}\text { Mainly or entirely } \\
\text { informal }\end{array}$ & $\begin{array}{c}\text { Informal and } \\
\text { formal }\end{array}$ & $\begin{array}{c}\text { Mainly or } \\
\text { entirely formal }\end{array}$ \\
\hline $\begin{array}{l}\text { Executive politicians and advisory } \\
\text { bodies (15) }\end{array}$ & $40.0 \%(20.8 \%)$ & $40.0 \%(53.4 \%)$ & $20.0 \%(25.8 \%)$ \\
$\begin{array}{l}\text { Civil servants (16) } \\
\text { Political parties, legislative }\end{array}$ & $31.3 \%(22.0 \%)$ & $25.0 \%(52.1 \%)$ & $43.8 \%(25.9 \%)$ \\
politicians, and think tanks (25) & $48.0 \%(29.4 \%)$ & $36.0 \%(50.1 \%)$ & $16.0 \%(20.5 \%)$ \\
$\begin{array}{l}\text { International organizations (19) } \\
\text { Interest groups and other civil }\end{array}$ & $36.8 \%(17.9 \%)$ & $36.8 \%(56.1 \%)$ & $26.3 \%(26.0 \%)$ \\
society organizations (20) & $52.6 \%(31.1 \%)$ & $26.3 \%(48.8 \%)$ & $21.1 \%(20.1 \%)$ \\
Total (34) & $38.2 \%(31.3 \%)$ & $41.2 \%(46.5 \%)$ & $20.6 \%(22.2 \%)$ \\
\hline
\end{tabular}

Source: ProSEPS survey data.

It seems that policy advice in Hungary overall is somewhat more informal than the European average, while this difference is considerable in the case of recipients for whom personal connections are key: executive politicians and advisory bodies, legislative politicians and (ideologically aligned) think tanks, and civil society organizations. While this relationship is weaker in the case of advice provided to civil servants and international organizations, these recipients are still more likely to seek informal advice in Hungary than in Europe on average. Note that respondents could indicate multiple recipients and an overall level of formality, so the high level of informality in most categories may result from an active group of 
academics having informal talks with many actors (thus affecting several rows), while those with more formal advisory activities have more concentrated relations, affecting the results vis-à-vis a few recipients. This could also account for the composition effect, where the overall difference in the formality of advice between Hungary and the European average is smaller than for any recipient. The modes of advice dissemination reflect the prevalence of informality, where the most frequent activities are those involving personal meetings, with $40.9 \%$ of respondents giving policy advice on a face-to-face basis at least once a year and $39.4 \%$ via workshops or conferences.

\subsubsection{Determinants and Alternative Strategies of Access}

We can better understand patterns of access by comparing those who remain outside with those involved, albeit in mostly unfavourable circumstances. The two filters of engagement together lead us to expect both age and gender to be important determinants of access, for three reasons. First, changing academic norms in political science mean that the older colleagues, who are more likely to be male, are also more likely to be public intellectuals or opinionating scholars. Second, academic position also impacts results here, as women and younger researchers will likely have to concentrate more on core academic activities in order to get a foothold in the profession, leaving less time and energy for advisory activities, which are not taken into account in performance assessment. Lastly, we expect a significant degree of homophily in informal advisory linkages, whereby older, male PSs are more likely to be part of the 'in-group' with access to government policymaking, since older men still dominate Hungarian politics. Thus, age and gender act as proxies of personal connections with politicians and other policymakers.

Do younger academics choose different channels and forms of advice, in order to gain access to, and to affect, policymaking? Table 9.6 displays the average age of political scientists grouped by recipients of their advice. The only significant age difference (of 7.1 years) is found between those who advise international organizations and those who do not. A less significant impact of age on access to the recipients of advice are visible when those recipients are executive politicians, advisory bodies, political parties, legislators, and think tanks. Political scientists advising civil society organizations and civil servants are comparatively younger. Age also appears to have quite modest effects in terms of role types. 
Table 9.6 Average age of respondents by recipients of advice-Hungary

\begin{tabular}{|c|c|c|c|c|}
\hline \multirow[t]{3}{*}{ Recipients of advice (n) } & \multicolumn{4}{|c|}{ Average age (in years) } \\
\hline & \multicolumn{2}{|c|}{ Hungary $(n=65)$} & \multicolumn{2}{|c|}{ Overall sample } \\
\hline & Selected & Not selected & Selected & Not selected \\
\hline $\begin{array}{l}\text { Executive politicians and advisory } \\
\text { bodies }(23)\end{array}$ & 45.4 & 43.3 & 48.0 & 44.9 \\
\hline Civil servants $(16)$ & 41.8 & 44.8 & 47.2 & 45.4 \\
\hline $\begin{array}{l}\text { Political parties, legislative politicians, } \\
\text { and think tanks }(25)\end{array}$ & 46.8 & 42.4 & 47.2 & 44.8 \\
\hline International organizations (19) & 49.1 & 42.0 & 46.8 & 45.5 \\
\hline $\begin{array}{l}\text { Interest groups and other civil society } \\
\text { organizations }(20)\end{array}$ & 43.6 & 44.3 & 48.4 & 45.4 \\
\hline Total (34) & 44.1 & & 46.2 & \\
\hline
\end{tabular}

Source: ProSEPS survey data.

How does gender impact engagement in advisory activities? Our data indicate that men are more likely to be opinionating scholars $(34.5 \%$ against $23.1 \%$ for women), whereas women are more likely to be experts (23.1\% against $13.8 \%)$. If this may suggest a gender influence on role type choice, two of the three public intellectuals in our sample are women. Here it appears that experience in political office also has an effect.

Table 9.7 gives further details of the communication channels of advice used by female and male political scientists. The first four modes all rely on the existence of personal connections between advisor and recipient, and all modes are more likely to be frequently used by men. This is in keeping with the expectation of males being more likely to have access through their personal connections.

For the other channels except traditional media articles, we find that female political scientists use these more frequently. Making sense of this pattern, there is a relationship with the advisory role type: channels that go with an expert role are more prominent for female scholars, while opinionating, in which male scholars are more active and visible, is more closely connected to informal communication modes and media article writing. 
Table 9.7 Modes and channels of advice by gender-Hungary

\begin{tabular}{|c|c|c|c|c|c|c|c|}
\hline & Gender & $\begin{array}{c}\text { At least } \\
\text { once a } \\
\text { week }\end{array}$ & $\begin{array}{l}\text { At least } \\
\text { once a } \\
\text { month }\end{array}$ & $\begin{array}{l}\text { At least } \\
\text { once a } \\
\text { year }\end{array}$ & $\begin{array}{c}\text { Less } \\
\text { frequently }\end{array}$ & Never & n.a. \\
\hline \multirow{4}{*}{$\begin{array}{l}\text { Face-to-face with } \\
\text { actor/organization } \\
\text { Over phone to actor/ } \\
\text { organization }\end{array}$} & Female & $4.8 \%$ & $14.3 \%$ & $9.5 \%$ & $4.8 \%$ & $19.0 \%$ & $47.6 \%$ \\
\hline & Male & $2.2 \%$ & $17.8 \%$ & $26.7 \%$ & $6.7 \%$ & $0.0 \%$ & $46.7 \%$ \\
\hline & Female & $0.0 \%$ & $9.5 \%$ & $4.8 \%$ & $9.5 \%$ & $28.6 \%$ & $47.6 \%$ \\
\hline & Male & $11.1 \%$ & $8.9 \%$ & $13.3 \%$ & $6.7 \%$ & $13.3 \%$ & $46.7 \%$ \\
\hline \multirow{2}{*}{$\begin{array}{l}\text { By email or post to } \\
\text { actor/organization }\end{array}$} & Female & $9.5 \%$ & $0.0 \%$ & $9.5 \%$ & $0.0 \%$ & $33.3 \%$ & $47.6 \%$ \\
\hline & Male & $13.3 \%$ & $13.3 \%$ & $6.7 \%$ & $11.1 \%$ & $8.9 \%$ & $46.7 \%$ \\
\hline \multirow{2}{*}{$\begin{array}{l}\text { Via workshop or } \\
\text { conference }\end{array}$} & Female & $0.0 \%$ & $4.8 \%$ & $28.6 \%$ & $9.5 \%$ & $9.5 \%$ & $47.6 \%$ \\
\hline & Male & $2.2 \%$ & $8.9 \%$ & $31.1 \%$ & $8.9 \%$ & $2.2 \%$ & $46.7 \%$ \\
\hline \multirow{2}{*}{$\begin{array}{l}\text { Traditional media } \\
\text { articles }\end{array}$} & Female & $4.8 \%$ & $0.0 \%$ & $0.0 \%$ & $9.5 \%$ & $38.1 \%$ & $47.6 \%$ \\
\hline & Male & $2.2 \%$ & $6.7 \%$ & $4.4 \%$ & $24.4 \%$ & $15.6 \%$ & $46.7 \%$ \\
\hline \multirow[t]{2}{*}{ Blog/social media } & Female & $7.1 \%$ & $21.4 \%$ & $7.1 \%$ & $7.1 \%$ & $14.3 \%$ & $42.9 \%$ \\
\hline & Male & $3.4 \%$ & $3.4 \%$ & $13.8 \%$ & $10.3 \%$ & $20.7 \%$ & $48.3 \%$ \\
\hline \multirow{2}{*}{$\begin{array}{l}\text { Training courses for } \\
\text { policy actors, } \\
\text { administrative } \\
\text { organizations, other } \\
\text { actors }\end{array}$} & Female & $7.1 \%$ & $21.4 \%$ & $7.1 \%$ & $7.1 \%$ & $14.3 \%$ & $42.9 \%$ \\
\hline & Male & $3.4 \%$ & $3.4 \%$ & $13.8 \%$ & $10.3 \%$ & $20.7 \%$ & $48.3 \%$ \\
\hline \multirow{2}{*}{$\begin{array}{l}\text { Policy reports, policy } \\
\text { briefs, memos }\end{array}$} & Female & $7.1 \%$ & $14.3 \%$ & $7.1 \%$ & $7.1 \%$ & $21.4 \%$ & $42.9 \%$ \\
\hline & Male & $0.0 \%$ & $3.3 \%$ & $6.7 \%$ & $26.7 \%$ & $16.7 \%$ & $46.7 \%$ \\
\hline \multirow[t]{2}{*}{ Research reports } & Female & $7.1 \%$ & $7.1 \%$ & $28.6 \%$ & $7.1 \%$ & $7.1 \%$ & $42.9 \%$ \\
\hline & Male & $0.0 \%$ & $10.3 \%$ & $17.2 \%$ & $17.2 \%$ & $6.9 \%$ & $48.3 \%$ \\
\hline \multirow{2}{*}{$\begin{array}{l}\text { Publications (books, } \\
\text { articles) }\end{array}$} & Female & $4.8 \%$ & $9.5 \%$ & $19.0 \%$ & $14.3 \%$ & $4.8 \%$ & $47.6 \%$ \\
\hline & Male & $0.0 \%$ & $6.7 \%$ & $22.2 \%$ & $15.6 \%$ & $6.7 \%$ & $48.9 \%$ \\
\hline
\end{tabular}

Source: ProSEPS survey data.

\subsection{Discussion: Towards a Populist Policy AdVISORY System?}

In Hungary, the level and types of advisory activity of political scientists is more limited by demand-side factors than by the supply side of knowledge production and by viewpoints within the scholarly community itself. While the academic arena may only provide weak incentives for advisory activity, financial considerations on the other hand may drive scholars towards offering their advisory services. The main obstacle to the greater engagement of political scientists lies in the lack of fit between the advisory expectations or claims of the dominant policy actors and what political scientists are actually able to provide. 
The goal of this chapter was to provide a clearer understanding of how political scientists do or do not cope with the features of the closed policy process with its limited number of institutionalized access points. Expectations regarding the viewpoints and behaviour of political scientists in Hungary were compared with the responses to survey questions. Only one of the expectations on policy advice in the illiberal-populist system of governance in Hungary was not corroborated by the survey results: despite the expected importance of political polling and consulting activities and normative considerations, advisory activities were dominated, instead, by substantive advice and analysis, albeit mostly outside of traditional core PS subfields. The other observed features of policy advice met our expectations very closely. The national level of governance dominates the policy advisory system, just as it does policymaking. The externalization of policy capacities is clearly visible in the key position taken by think tanks, in the moderating role of firms, and in the small share of total advice received by advisory bodies and internal governmental actors.

The connections between expertise and governance seem to be underinstitutionalized in general, while it is through cultivating personal connections that academics are able to have a significant advisory impact without enjoying institutionalized access points. This leads to highly informal advice right across the policy advisory system. The closed advisory system with its selective, often personalized, gender-biased access points also leads to different channels being used by male and female academics. An additional important aspect of our portrayal of the illiberal-populist policy advisory system consists in the significant relative weight of international advisory activities, which may be the natural outcome of the contraction and closing of the domestic system, but which could also be the result of international actors looking to understand and deal with the unpredictable patterns of domestic policymaking.

How generalizable are these results to the policy advisory system as a whole? Political science might be in a privileged position due to its relationship to the political considerations underlying policymaking. Academics from other disciplines may be less capable and willing to navigate the politicized landscape and to cultivate personal connections, thus leading to their even higher rate of exclusion and passivity. As knowledge areas and activities specifically linked to political science were found to be relatively unimportant for advice given by political scientists, our findings may approximate how academics more generally fit into the policy advisory system of Hungary. 
This first overview of the Hungarian policy advisory system including systematic empirical data forms part of the enigma of the existence or otherwise of a more general illiberal-populist policy advisory model. A crosssectional analysis does not enable us to establish how much of the closed and informal nature of the system presented here is driven by Hungarian political traditions and how much is due to recent developments. The chapter on Turkey provides another look at an illiberal regime with populist tendencies and a policy advisory system with many similar features, but in order to reach any systemic conclusions, other cases of populist policymaking, such as the rather similar case of Poland, need to be analysed. It is also worth asking whether the connections between underinstitutionalization, the externalization of advice, informality, and selective access can be substantiated in other contexts.

\section{REFERENCES}

Bandola-Gill, J., Brans, M., \& Flinders, M. (2018). Incentives for impact in higher education: A cross-national political science perspective (p. 26). Report to EU COST Action ProSEPS - Professionalization and Social Impact of European Political Science. http://proseps.unibo.it/wp-content/uploads/2018/10/ Sarajevo-paper-impact.pdf

Bartha, A., Boda, Z., \& Szikra, D. (2020). When Populist Leaders Govern: Conceptualizing Populism in Policy Making. Politics and Governance, 8(3), 71-81. https://doi.org/10.17645/pag.v8i3.2922

Bíró-Nagy, A. (2019). Agytrösztök. In Sebők. M. and Böcskei. B. (eds.), Itt van Amerika - Az amerikai politika hatása Magyarországon (pp. 70-84). Athenaeum. http://real.mtak.hu/104648/

Boda, Z., \& Patkós, V. (2018). Driven by politics: Agenda setting and policymaking in Hungary 2010-2014. Policy Studies, 39(4), 402-421. https://doi. org/10.1080/01442872.2018.1478075

Bozóki, A., \& Hegedűs, D. (2018). An externally constrained hybrid regime: Hungary in the European Union. Democratization, 25(7), 1173-1189. https://doi.org/10.1080/13510347.2018.1455664

Gajduschek, G. (2012). A magyar közigazgatás és közigazgatás-tudomány jogias jellegéről. Politikatudományi Szemle, 4, 29-49.

Hajnal, G. (2020). Public Administration in Hungary: Emerging Dynamics in an Illiberal Democracy. In Bouckaert, G. \& Jann, W. (eds.), European Perspectives for Public Administration, 367-386. Leuven University Press; JSTOR. https:// doi.org/10.2307/j.ctvv417th.23

Hajnal, G., Kádár, K., \& Kovács, É. (2018a). Government Capacity and CapacityBuilding in Hungary: A New Model in the Making? NISPAcee Journal of Public 
Administration and Policy, 11(1), 11-39. https://doi.org/10.2478/ nispa-2018-0001

Hajnal, G., Kádár, K., \& Kovács, É. (2018b). Public administration characteristics and performance in EU28: Hungary. Directorate-General for Employment, Social Affairs and Inclusion (European Commission). https://doi. org $/ 10.2767 / 507616$

Hajnal, G., \& Rosta, M. (2019). A New Doctrine in the Making? Doctrinal Foundations of Sub-National Governance Reforms in Hungary (2010-2014). Administration \& Society, 5l(3), 404-430. https://doi.org/10.1177/ 0095399715626202

Hajnal, G., \& Ványolós, I. (2013). Hungarian public administration: From transition to consolidation. In L. Saltanat, S. E. Condrey, \& D. Goncharov (Eds.), Public administration in post-Communist countries. Former Soviet Union, Central and Eastern Europe, and Mongolia (pp. 1-14). CRC PRESS. http:// real.mtak.hu/10084/

Ilonszki, G., \& Roux, C. (2019). The State of Political Science in Europe. ProSEPS Report by Working Group 1. Report to EU COST Action ProSEPS Professionalization and Social Impact of European Political Science. http:// proseps.unibo.it/wp-content/uploads/2019/09/Working-Group-1-ReportThe-State-of-Political-Science.pdf

Korkut, U. (2012). Liberalization Challenges in Hungary: Elitism, Progressivism, and Populism. Palgrave Macmillan, New York. https://doi. org/10.1057/9781137075673

Körösényi, A. (2003). Politikai képviselet a vezérdemokráciában. Politikatudományi Szemle, 12(4), 5-22.

Körösényi, A., Illés, G., \& Gyulai, A. (2020). The Orbán Regime: Plebiscitary Leader Democracy in the Making. Routledge. https://doi.org/10.4324/ 9780429053436

Körösényi, A., Tóth, C., \& Török, G. (2009). The Hungarian Political System. Budapest, Hungarian Center for Democracy Studies Foundation.

Meyer-Sahling, J.-H. (2006). The rise of the partisan state? Parties, patronage and the ministerial bureaucracy in Hungary. Journal of Communist Studies and Transition Politics, 22(3), 274-297. https://doi.org/10.1080/ 13523270600855662

Meyer-Sahling, J.-H., \& Veen, T. (2012). Governing the post-communist state: Government alternation and senior civil service politicization in Central and Eastern Europe. East European Politics, 28(1), 4-22. https://doi.org/10.108 $0 / 13523279.2011 .635651$

Molnár, G. T., \& Ilonszki, G. (2021). Identity formation of the profession in a latecomer political science community. European Political Science, 20(1), 139-158. https://doi.org/10.1057/s41304-021-00318-w 
Mudde, C., \& Jenne, E. K. (2012). Hungary's Illiberal Turn: Can Outsiders Help? Journal of Democracy, 23(3), l. https://works.bepress.com/ cas_mudde $/ 62 /$

Pappas, T. S. (2014). Populist Democracies: Post-Authoritarian Greece and PostCommunist Hungary. Government and Opposition, 49(1), 1-23. https://doi. org/10.1017/gov.2013.21

Staroňová, K., \& Gajduschek, G. (2013). Civil Service Reform in Slovakia and Hungary: The Road to Professionalization? In C. Neuhold, S. Vanhoonacker, \& L. Verhey (Eds.), Civil Servants and Politics: A Delicate Balance (pp. 123-151). Palgrave Macmillan. https://doi.org/10.1057/ 9781137316813_8

Szabó, M. (2010). A magyar politikatudomány helyzete 2010-ben. Politikatudomanyi Szemle, 19(4), 16.

Szelényi, I., \& Csillag, T. (2015). Drifting from liberal democracy. Neoconservative ideology of managed illiberal democratic capitalism in post-communist Europe | Intersections. East European Journal of Society and Politics, 1(1), 18-48. https://doi.org/10.17356/ieejsp.vlil.28

Ványi, É. (2018). Political Predation or Personal Loyalty? POLITICAL SCIENCE ONLINE, Special Issue, 14.

Open Access This chapter is licensed under the terms of the Creative Commons Attribution 4.0 International License (http://creativecommons.org/licenses/ by $/ 4.0 /$ ), which permits use, sharing, adaptation, distribution and reproduction in any medium or format, as long as you give appropriate credit to the original author(s) and the source, provide a link to the Creative Commons licence and indicate if changes were made.

The images or other third party material in this chapter are included in the chapter's Creative Commons licence, unless indicated otherwise in a credit line to the material. If material is not included in the chapter's Creative Commons licence and your intended use is not permitted by statutory regulation or exceeds the permitted use, you will need to obtain permission directly from the copyright holder.

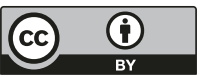

